\title{
on_education
}

Journal for Research and Debate

\section{reflecting on the meaning of academic life}

\begin{abstract}
Ali Black
Stefan Collini, in his book 'What are Universities For', describes the importance of reflection and contemplation on the meaning of academic life. As a way of encouraging such reflection, I begin with my own story. For me, sharing stories is a way to resist the neoliberal university and the emotional and physical weight of its deadening and narrow metric-oriented measures. So, my contribution to this special issue on Academic Lives is contextualized in meaning making, in my own academic life and my personal/professional experiences.
\end{abstract}

Introduction

Stefan Collini, in his book What are Universities For, describes the importance of reflection and contemplation on the meaning of academic life (Collini, 2012). As a way of encouraging such reflection, I begin with my own story. For me, sharing stories is a way to resist the neoliberal university and the emotional and physical weight of its deadening and narrow metric-oriented measures. So, my contribution to this special issue on Academic Lives is contextualized in meaning making, in my own academic life and my personal/professional experiences. It is imbued with my desire for academics to bring themselves into their work, their institutions, their research writing, teaching, and scholarly contribution, and to make both "barriers and strategies visible" (Haynes \& Pedersen, 2018).

I have been in academia a long time - more than 20 years. I began as a 27 -year-old and was the youngest in my faculty. I experienced the isolating realities of "publish or perish" immediately with my $\mathrm{PhD}$ commencement and completion a requirement of my five-year probation period and a condition of ongoing employment. I experienced the strained relationship between building an academic track record and life circumstances. Remembering these early years of "becoming academic" is startling. During the beginning weeks of this entry into academe my first marriage ended, and my beloved grandmother died days after. There was little time to grieve; I worked on my $\mathrm{PhD}$ (studying part-time while working in academe full time) and visited my incarcerated father most weekends. My mother moved from her well-loved home into a retirement village where she had several operations and multiple brushes with death and I bought a house where I was subsequently burgled three times. My divorce finalized and I started a new relationship, moved residence four more times, got married, and negotiated the blending of families. In the year my $\mathrm{PhD}$ was completed and conferred, my son was conceived and born. Somehow, by the five-year mark, despite all this, I had met the probation stipulations and secured tenure.

My academic work/life has always required a lot of me and there are times I feel disheartened that I have little to show for my energy and commitment in terms of status and position. In addition, facing the pressure of an institutional culture focused on speed, volume, comparison, competition, 
and accountability has been, on occasion, overwhelming (Black, 2018). During certain periods, I have relied on anti-depressants to help me through and I have in turn resisted and then succumbed to the academy's stress-inducing emphasis on "doing more", "juggling much" and "measuring everything". Equally, I have come to recognize the importance of approaching the pace and complexity of our lives and work with "care and attention" and in meaningful, thoughtful, and nourishing ways (Parkins \& Craig, 2006).

I first wrote about "becoming academic" on my own (Black, 2015) and then with my friend and colleague Dr. Sarah Loch (Black \& Loch, 2014; Loch \& Black, 2016). As we reflected on the enormous interweaving of our personal and professional lives, we recognized "we simply cannot do this work without being who we are" (Loch \& Black, 2016).

Over my academic career I have sometimes been asked to explain my "gaps" in productivity with little regard for the reasons behind such "career interruptions". I would like to think that this doesn't happen anymore and that the university is kinder and more aware. Alas, I know this is not the case.

The nature of academic work

The nature and uncertainty of academic work in these contemporary times is well documented, with academics around the world experiencing pressure to lead and live "affectively thin and relentlessly diagnostic lives' due to the "steady poisoning and paralyzing effects of managerialism" (Collini, 2012). Stress in academia exceeds that found in the general population (Catano et al., 2010) and the intensification of academic work linked to corporate and managerialist approaches have brought significant changes which threaten academic workplaces, identities and autonomy (Addison \& Mountford, 2015; Gill, 2009; Henkel, 2005; Marginson, 2000; Petersen \& Davies, 2010). In this increasingly corporatized academy, productivity and outputs are rewarded, with little consideration given to the complex experience of being human (Harre, Grant, Locke, \& Sturm, 2017). Some liken academia to zombiedom (Whelan, Walker, \& Moore, 2013) and machine-like production (Henderson, Honan, \& Loch, 2016). Competition and measurement have become the order of the day. Managerial cultures breed individualism and ruthlessness producing what Kathleen Lynch (2010) describes as a "care-less" profession. As Catherine Manathunga and Dorothy Bottrell (2018, p. 309) identify "these developments have grave consequences not just for universities and the staff and students that work within them, but also for human societies as a whole". Heeding Maggie O'Neill (2014), it is time to pause, reflect upon and resist the relentless performativity and measurement of academic life.

Our own (and others') stories help us to see that collective conversations about how we make sense of academic culture and social, political and intellectual life in the academy are needed. They help us understand that we must envision something new, something beyond what neoliberalism is offering. We must resist, speak up, and act from where we are (Walsh, 2018; Henderson \& Black, 2018). Pereira (2015) suggests an ethic of care. Caring is crucial if we are to resist the competitiveness, measurement, self-promotion and isolating effects of the increasing demands that pervade the academy.

Sarah and I, in our writing as research, voiced out loud our experiences of/inside/outside academia in the hope that:

"work like ours will help more researchers find ways to tell their academic communities how they 
do the work they do and who they are whilst they do it. There is richness in connecting with others but we must not forget why we research. It isn't just a game of citations, funding, getting in the best journals; it is about engaging with the lives and stories and experiences of others, and being changed by these, understanding things about others and ourselves that we wouldn't have been able to without this interaction, without these methodologies." (Loch \& Black, 2016, p. 119-120).

Through our writing together, we have urged others towards aesthetic methodologies - creative writing, autoethnography, art, poetry, representations of thinking - as ways of exposing and disclosing "the heart of our humanness" (Loch \& Black, 2016, p. 120).

Disclosing the "heart of our humanness" in academia

My responses here and across my recent research writing with others, are infused by my desire to "be" differently in academia. They are also influenced by my collective writing and research with other women (which seeks to shed light on women's academic experiences, to make public the stories of what it has felt like and feels like to be a female academic). As, "it is through coauthorship and sharing, that we might together shape the academe we want rather than the academe we have" (Netolicky, Barnes, \& Heffernan, 2018, p. 180). Collective writing and the sharing of personal/professional experiences, of the messiness of inner/academic/personal lives generates opportunities and possibilities. Such a reconciliation of complexity is a refusal to accept the quantifying delimiters of academic production, and instead is an agentic way of embracing work lives that are reflective, spacious and pleasurable (Black, Crimmins, \& Jones, 2017).

Laurel Richardson (2008, p. 1) writes encouragingly to those of us who seek to work, write and connect in this heart-disclosing-landmark-laying-down-kind-of-way: "You are the ones who cho[o]se to act differently, to respond to your callings, to build community, to welcome others". This kind of acting differently, of welcoming others and their stories, is as Jeanette Rhedding-Jones (2005, p. 148) emphasized "a crucial quality of research" because "seen personally, research is about surviving the workplace and then transforming both it and yourself". Writing and sharing the heart of our humanness creates spaces to "feel the reverberations of feelings, thought, images, bodily sensations" (Walsh \& Bai, 2015, p. 29). It offers opportunities that press back against neoliberalism's isolation, elitism and rivalry, to embrace ethics of care and caring.

Christopher Poulos (2014, p. 1007) describes relation as "that which is said, and that which is not said, that which is present, and that which is absent - the whole array of co-constructed meanings that emerge from human encounter". We can engage in human encounters in academe in a range of ways, with technology expanding the possibilities, but we must engage.

I am the founder of a writing collective called "The Women Who Write". Spread across Australia, we have consciously cultivated connection yet few of us have met in person more than once, connecting instead via video conferencing and email. We have found friendship and have written prolifically with an "enhanced spirit of enquiry, and more intelligence, deductive speed, and inventiveness than we possess as individuals" (Brennan, 2004, p. 62). We have equally come to understand that our stories and the her-stories of women matter (Henderson, Black, Crimmins, \& Jones, in press).

On Facebook, I also connect with a group called "Women in Academia Support Network" \#wiasn. It is a place for academics who identify as women, to share their experiences of professional and 
family life and it has more than ten thousand members from around the globe. Here women both give and seek support. They ask and answer everyday, practical questions and hard questions too, questions which showcase the dilemmas of being a woman in academia, for example: "At what point do you think it is time to give up on a career in academia?" "Is there a particular point in an academic career/completing a $\mathrm{PhD}$ when it is best to have children?" "Is an academic career conducive to being a parent?" "How do people cope with imposter syndrome?" "What do you wish you knew about the responsibilities that came alongside your job?"

Perhaps not surprisingly, I care about the experiences of women in academia. With my colleague Professor Susanne Garvis, I have recently co-edited two books Lived Experiences of Women in Academia (Black \& Garvis, 2018a) and Women Activating Agency in Academia (Black \& Garvis, 2018b). Across these books, 65 female academics from nine countries share their lived experiences of academia. Their stories cover work realities, career stages, identities, cultures, roles, emotions, ethics, relationships, strategies and opportunities.

Sensing the importance of spaces for women to share their experience, Susie and I subsequently collected data via a survey "I am a woman and I work in academia: An international collection of female academics" perspectives and experiences of their work" (Black \& Garvis, 2018c). We are still analyzing data and writing up findings as more than 640 women from 31 countries responded. Of these women, less than half have secured a permanent position and $60 \%$ are unable to picture themselves working in academia 10 years from now. More than half of the respondents are dissatisfied with their work-life balance and when asked to describe an image that communicates their experience of being a woman in academia, they share descriptions like these:

"I used to feel a sense of freedom, excitement and opportunity. Now, I feel like a person trying to shoulder a heavy load. As the load becomes heavier each year, I struggle to hold it up, becoming more bent as I try to stop it from crushing me. I feel the weight of expectations on me as mother/wife/worker and the increasing workload as funding has been ripped away from the sector."

"Stretched tight in every direction, with men holding big magnifying glasses to check the academic outputs. No eyes, no hearts, no brains. A different culture would yield such different fruit and a healthier workplace culture."

"Walking in deep marshes."

"The future is sessional."

"Watching someone else get first prize after he came in second."

"I feel alone."

"Imagine someone strapped to one of those medieval torture devices they used to stretch people, being pulled in multiple disciplinary directions. At the same time, one of those giant anvils is crushing you, and around you stand colleagues asking when you will finish your book, how many articles you will publish this year, and if you will work for free at the postgraduate fair this weekend."

"Running full pelt toward a goal which is moved at the last minute and anyway someone just tackled you, took the ball and scored the goal themselves. I don't want or need to be the goal scorer but I do want fair treatment and support for new ideas." 
"Be bold, formidable and highly successful. Nothing less will do! If you have children/family so what! We expect more, more, more!' This sounds negative. It is I guess, but I am being very honest. If I was to create a metaphor of what I wish was my experience it would be: Think, read, think, write, read, stimulate new thinking and change."

"I am a child on a beach, building sandcastles in an incoming and outgoing tide. Each sandcastle is something valuable: a capacity to speak, to be heard, to exist, to be present. Each incoming tide shakes or destroys the sandcastles. But each time I build them up again, and they are clearer, more defined, bigger, more defiant. I am learning the skills to make myself endure, and beyond that, sometime in the future, to thrive."

"Like a lotus we rise above the mud." (Black \& Garvis, 2018c).

Shaping the university as a place to realize a special way of living one's life: is it possible?

Thinking beyond the present and developing something new requires us to "prise open the cracks in neoliberalism and [re]create the conditions for radical hope in the academy" (Manathunga \& Bottrell, 2018, p. 309). The notion of radical hope appeals to me - I like to believe we can "shape the academy we want, rather than the academy we have" (Netolicky, Barnes, \& Heffernan, 2018, p. 180); that like a lotus we can rise above the mud.

My own experience shows me that we rise by working collectively and collaboratively (Wright, Cooper, \& Luff, 2017) with an ethic of care and caring (Mountz et al., 2015), by sharing stories (Black, Crimmins, \& Jones, 2017) and by counting differently (Harre, Grant, Locke, \& Sturm, 2017; Walsh, 2018).

Dennis Haskell (2016) has created a collection of verse where he takes the reader into what he calls "the other country", a country of personal experience. If we are to experience a hopeful, soulful life in academia, then we must disclose "the heart of our humanness" (Loch \& Black, 120) and venture into "the other country" (Haskell, 2016) - a place outside and away from the counting culture. In this "other country" we resist the "overwhelming bureaucratic impulse to speed up academic production and make academics into tacticians preoccupied with the game of professional standing" (Back, 2016, p. 11) and instead, in the company of others, we cultivate sacred spaces for care-full exchanges about what it is like to live an academic life (Henderson \& Black, 2018). In this "other country" we think, feel and speak differently and we open into different ways of knowing and being, bringing our whole selves into our work and research (Walsh, 2018). We perceive things that matter and things that require contemplation and care. We make space for research that makes a difference. We let go of things that once held us down and "[break] free...of discourses [we] have [internalized] as Western [men/] women/academic[s]/writer[s]" (Walsh, 2000, n.p.).

We realize a special way of living an academic life as we realize "our potential as people living together to be open and inclusive, and to promote the life, and growth, that helps us flourish as individuals and communities" and as we "[imagine] a world in which our heartfelt, personal response to life, our deep listening to others (especially those who don't fit in), and our careful observations and thought about the social, natural and physical world come together to create and recreate our institutions" (Harre, Grant, Locke, \& Sturm, 2017, p. 5).

Let's venture together to this other country, listen to each other's stories, imagine something kinder and recreate a thoughtful and socially just academy. 
Addison, M., \& Mountford, V. (2015). Talking the talk and fitting in: Troubling the practices of speaking 'what you are worth' in higher education in the UK. Sociological Research Online, 20(2), $1-13$.

Back, L. (2016). Academic diary: Or why higher education still matters. London: Goldsmiths Press. Black, A. L. (2015). Authoring a life: Writing ourselves in/out of our work in education. In Baguley, M., Findlay, Y., \& Kirby, M. C. (Eds.), Meanings and Motivation in Education Research (pp. 72-94). London: Routledge.

Black, A. L. (2018). Responding to longings for slow scholarship: Writing ourselves into being. In Black, A. L., \& Garvis, S. (Eds.), Women Activating Agency in Academia: Metaphors, Manifestos and Memoir (pp. 23-34). Abingdon: Routledge.

Black, A. L., Crimmins, G., Jones, J. K. (2017). Reducing the drag: Creating V formations through slow scholarship and story. In Riddle, S., Harmes, M., \& Danaher, P. A. (Eds.), Producing pleasure within the contemporary university (pp. 137-155). Rotterdam: Sense Publishing.

Black, A. L., \& Garvis, S. (2018a). Lived Experiences of Women in Academia: Metaphors, Manifestos and Memoir. Abingdon UK: Routledge.

Black, A. L., \& Garvis, S. (2018b). Women Activating Agency in Academia: Metaphors, Manifestos and Memoir. Abingdon: Routledge.

Black, A. L, \& Garvis S. (2018c). International Survey: I am a woman and I work in academia: An international collection of female academics' perspectives and experiences of their work. Ethics number A/16/901. University of the Sunshine Coast.

Black, A. L, \& Loch, S. (2014). Called to respond: The potential of unveiling hiddens. Reconceptualizing Educational Research Methodology, 5(2), 60-75. DOI: https://doi.org/10.7577/rerm.1221

Brennan, T. (2004). The transmission of affect. Ithaca: Cornell University Press.

Catano, V. M., Francis, L., Haines, T., Kirpalani, H., Shannon, H., Stringer, B., \& Lozanski, L. (2010). Occupational stress in Canadian Universities: A national survey. International Journal of Stress Management, 17, 232-258.

Collini, S. (2012). What are universities for? London: Penguin.

Gill, R. (2009). Breaking the silence: The hidden injuries of neo-liberal academia. In Flood, R., \& Gill, R. (Eds.), Secrecy and silence in the Research Process: Feminist Reflections. London: Routledge.

Harre, N., Grant, B. M., Locke, K., \& Sturm, S. (2017). The university as an infinite game. The Australian Universities' Review, 59(2), 5-13.

https://search.informit.com.au/documentSummary; $\mathrm{dn}=075978014826402 ;$ res=IELAPA.

Haskell, D. (2016). Ahead of us. Freemantle: Freemantle Press.

Haynes, R., \& Pedersen, C. (2018). To care for self and others: A collaborative conversation. In Black, A. L., \& Garvis, S. (Eds.), Women Activating Agency in Academia: Metaphors, Manifestos and Memoir (pp. 174-184). Abingdon: Routledge.

Henderson, L., \& Black, A. L. (2018). Splitting the world open: Writing stories of mourning and loss. Qualitative Inquiry, 24(4), 260-269. DOI: https://doi.org/10.1177/1077800417728958

Henderson, L., Black, A. L., Crimmins, G., Jones, J.K. (in press). Sharing our names and remembering our her-stories: Resisting Ofuniversity. In Crimmins, G. (Ed.), Strategies for resisting sexism in the academy. Basingstoke: Palgrave Macmillan.

Henderson, L., Honan, E., Loch, S. (2016). The production of the academicwritingmachine. Reconceptualizing Educational Research Methodology, 7(2), 4-18.

Henkel, M. (2005). Academic Identity and Autonomy in a Changing Policy Environment. Higher Education, 49(1/2), 155-176. 
Loch, S., \& Black, A. L. (2016). We cannot do this work without being who we are: Researching and experiencing academic selves. In Harreveld, B., Danaher, M., Knight, B., Lawson, C., \& Busch, G. (Eds.), Constructing Methodology for Qualitative Research: Researching Education and Social Practices (pp. 105-122). Basingstoke: Palgrave Macmillan.

Lynch, K. (2010). Carelessness: A hidden doxa of higher education. Arts and Humanities in Higher Education, 9(1), 54-67.

Manathunga, C., \& Bottrell, D. (2018). Prising open the cracks through polyvalent lines of inquiry. In Manathunga, C., \& Bottrell, D. (Eds.), Resisting neoliberalism in universities: Prising open the cracks (pp. 293-320). Vol 2. London: Palgrave Macmillan.

Marginson, S. (2000). Rethinking Academic Work in the Global Era. Journal of Higher Education Policy and Management, 22(1), 23-35.

Mountz, A., Bonds, A., Mansfield, B., Loyd, J., Hyndman, J., Walton-Roberts, M., Basu, R., Whitson, R., Hawkins, R., Hamilton, T., \& Curran, W. (2015). For slow scholarship: A feminist politics of resistance through collective action in the Neoliberal University. ACME: An International Journal for Critical Geographies, 14(4), 1235-1259.

https://www.acme-journal.org/index.php/acme/article/view/1058.

Netolicky, D., Barnes, N., \& Heffernan, A. (2018). Metaphors for women's experiences of early career academia: Buffy, Alice, and Frankenstein's creature. In Black, A. L., \& Garvis, S. (Eds.), Lived Experiences of Women in Academia: Metaphors, Manifestos and Memoir (pp. 171-180). Abingdon: Routledge.

O'Neill, M. (2014). The slow university: Work, time and well-being. Forum Qualitative Sozialforschung / Forum: Qualitative Social Research, 15, 3. http://www.qualitativeresearch.net/index.php/fqs/article/view/2226/3696.

Parkins, W., \& Craig, G. (2006). Slow Living. Oxford: Berg.

Pereira, M. (2016). Struggling within and beyond the Performative University: Articulating Activism and Work in an «Academia Without Walls». Women's Studies International Forum, 54, 100-110.

Petersen, E. B., \& Davies, B. (2010). In/Difference in the neoliberalised university. Learning and Teaching, 3(2), 92-109.

Poulos, C. (2014). My father's ghost: A story of encounter and Transcendence. Qualitative Inquiry, 20(8), 1005-1014.

Rhedding-Jones, J. (2005). What is research? Methodological practices and new approaches. Oslo: Universitetsforlaget.

Richardson, L. (2008). Foreword: You changed my life. Creative Approaches to Research, 1(1), 1-2. Walsh, S. (2000). Writing with the dark. Language and Literacy, 2(2).

https://journals.library.ualberta.ca/langandlit/index.php/langandlit/article/view/17645/14002

Walsh, S. (2018). Contemplative and artful openings: Researching women and teaching. London: Routledge.

Walsh, S., \& Bai, H. (2015). Writing witness consciousness. Arts-based and contemplative practices in research and teaching: Honoring presence. New York: Routledge.

Whelan, A., Walker, R., \& Moore, C. (2013). Zombies in the academy: Living death in higher education. Bristol: Intellect Books.

Wright, H. R., Cooper, L., \& Luff, P. (2017). Woman's ways of working: Circumventing the masculine structures operating within and upon the University. Women's Studies International Forum, 61, 123-131.

\section{Recommended Citation}


Black, A.L. (2018). Reflecting on the Meaning of Academic Life. On Education. Journal for Research and Debate, 1 (3). https://doi.org/10.17899/on_ed.2018.3.4

\section{Download PDF version}

Do you want to comment on this article? Please send your reply to editors@oneducation.net. Replies will be processed like invited contributions. This means they will be assessed according to standard criteria of quality, relevance, and civility. Please make sure to follow editorial policies and formatting guidelines.

\section{alison I. black}

Dr. Alison L. Black is an arts-based and narrative researcher at the University of the Sunshine Coast, Australia. Ali is interested in autoethnographic, storied and visual approaches for supporting meaning-making, and the power and impact of collaborative and relational knowledge construction. She is working to create a kinder academy and is focused on spaces for female academics to share their experiences. See www.usc.edu.au/shift for an upcoming virtual exchange and (un)conference. More information about Ali's work can be accessed from her website http://www.draliblack.com/ 